Journal of Animal and Veterinary Advances 9 (18): 2422-2426, 2010

ISSN: $1680-5593$

(C) Medwell Journals, 2010

\title{
Prevalence of Trypanosomiasis in Ruminants in Parts of Abia State, Nigeria
}

\author{
C.C. Ohaeri \\ Department of Biological Sciences, Michael Okpara University of Agriculture, \\ Umudike P.M.B. 7267 Umuahia, Abia State Nigeria
}

\begin{abstract}
In a study of the prevalence of trypanosomiasis in ruminants in five regions of Abia State, Nigeria surveys were carried out at Isiukwuato, Ikwuano, Ohafia, Isiala Ngwa and Umuahia South Local Government areas. About 1361 ruminants made up of 405 cattle, 81 goats and 67 sheep were sampled monthly from April 2003-March 2004. Blood samples were examined for trypanosomes using the Giemsa stained thick and thin smear method. The results showed that the overall prevalence of trypanosomiasis in the State was $1.9 \%$. The prevalences in the different ruminant species were $3.7 \%$ in cattle, $1.2 \%$ in goats and $1.1 \%$ in sheep. Infection was lower $(\mathrm{p}<0.05)$ in animals resident in the State than those from semi-nomadic and slaughter houses. The overall difference in gender and age related infection were not obvious. Among the infected animals, 11 (42.3\%) and $15(57.7 \%)$ were due to $T$. congolense and $T$. vivax, respectively. $T$. vivax was the leading species encountered in cattle while $T$. congolense was more predominant in small ruminants. The result shows that the number of animals infected is significantly $(\mathrm{p}<0.001)$ dependent on time of the year, location sampled $\left(\chi^{2}=18.47\right.$, $\mathrm{df}=4, \mathrm{p}<0.001)$ and animal species $\left(\chi^{2}=7.89, \mathrm{df}=2, \mathrm{p}<0.05\right)$. This study brings to light that ruminants in the study area have low trypanosome infections and also confirms earlier observations by other researchers that goats and sheep which are exposed to a similar tsetse challenge as cattle are significantly less infected with trypanosomes than the latter.
\end{abstract}

Key words: Trypanosomiasis, ruminants, prevalence, blood, samples, T. congolense, T. vivax

\section{INTRODUCTION}

Tsetse-transmitted trypanosomiasis is still one of the most severe medical and veterinary problems in Africa, infecting around 50,000 people every year and preventing the development of sustainable and productive agricultural systems (Masiga et al., 2002). In many areas of endemic trypanosomiasis such as Nigeria, the epidemiology of the disease is poorly understood. Animal trypanosomiasis is also recognized as a major health problem in Nigeria. It is responsible for about $80 \%$ of Nigerian landscape being unsuitable for livestock production (Ugochukwu, 1983). In Nigeria, studies have been carried out in many areas especially in the North and in central Nigeria (Kalu and Lawani, 1996; Kalu et al., 1991, 2001).

Yet in some areas such as Abia State, the epidemiology of the disease is lacking. Additionally, the importance of sheep and goats in this area is poorly understood. This is unfortunate, since small ruminants are estimated to provide up to $30 \%$ of meat and $15 \%$ of milk production in sub-Sahara Africa (Luckins, 1992). In Abia State, cattle breeding do not flourish or is virtually non-existent: instead people keep goat, sheep or pig in most areas of the State as source of meat and income. This study will lay bare the prevalence of trypanosomiasis among small ruminants in Abia State, Nigeria.

\section{MATERIALS AND METHODS}

Study area: The study was conducted in Abia State, South-Eastern Nigeria. Abia State is located on latitude $4-6^{\circ} \mathrm{N}$, longitude $7-8^{\circ} \mathrm{E}$ and altitude $244-305 \mathrm{~m}$ (highest point) above sea level. Mean annual rainfall is $187.7 \mathrm{~mm}$. The soil is classified as ultisols by FAO standard.

Ruminant animals: A total of 1361 ruminants comprising of 405 cattle, 486 goats and 470 sheep were sampled. These ruminant assortments were recruited from: animals permanently resident in Abia State, semi nomadic animals and from slaughter houses (mostly bought from the north).

Diagnosis of trypanosomes in ruminants: The ages of the experimental animals were assessed through dental 
eruption and genders observed prior to blood collection. Blood was drawn from jugular vein of the animals after locating the vein with fingers and inserting the hypodermic needle.

About $3 \mathrm{~mL}$ of blood was collected per animal into an EDTA bottle which contained Ethylene Diamine Tetra-acetetic Acid (EDTA) as anticoagulant for detection of trypanosome infection using wet preparations then thin and thick blood smears stained with Giemsa stain (Murray et al., 1977; Paris et al., 1982).

Statistical analysis: The data obtained from this study were analysed using student's t-test and $\chi^{2}$-test. A p-value of $<0.05$ or less was considered significant.

\section{RESULTS AND DISCUSSION}

Prevalence of Trypanosoma species in ruminant animals: A total 1361 ruminant animals made up of 405 cattle, 486 goats and 470 sheep were examined and out of these $26(1.9 \%)$ were infected with Trypanosomes (Table 1). Cattle (15 of 405: 3.7\%) had significantly higher $\left(\chi^{2}=7.89, \mathrm{df}=2, \mathrm{p}<0.05\right)$ prevalence than goats and sheep (1.2 and $1.1 \%$, respectively).

The species found in this study were Trypanosoma congolense and $T$. vivax (with only one $T$. brucei occurring as mixed infection). T. vivax accounted for $57.7 \%$ of all the positive cases and these were more predominant in cattle while $42.3 \%$ of the positive cases were due to $T$. congolense, however these were more predominant in small ruminants. A single simultaneous infection ( $T$. congolense + T. brucei) was detected (3.8\%) and this was found in cattle.

Effect of gender on trypanosome infections in ruminants: The effect of gender of ruminants on rate of infection is shown in Table 2 . There was no significant difference ( $>>0.05$ ) in the overall infection in both genders.

However, infection was higher in male cattle than in female ones but in small ruminants there was no significant difference observed in males and females tested. T. vivax infection was higher in cattle $\left(\chi^{2}=19.12\right.$, $\mathrm{df}=1, \mathrm{p}<0.001)$ and more predominant in males than in females: small ruminant infection was more of $T$. congolense type irrespective of the gender.

Effect of age on trypanosome infections in ruminants: Age related prevalence of infection is shown in Table 3 . Adult small ruminants recorded higher infection than their younger counterpart, however this difference was not statistically significant ( $\mathrm{p}>0.05$ ).

In cattle, infection was higher $(\mathrm{p}<0.05)$ in young animals $(4.8 \%)$ than in adult ones $(3.3 \%)$. There was no age related significant difference $(p>0.05)$ in the overall infection.

Effect of season of the years on ruminant trypanosomiasis: The effect of season on prevalence of infection is shown in Table 4. For each ruminant species infection was significantly higher $(p<0.001)$ during the rainy season than in the dry season.

Table 1: Prevalence of Trypanosoma species in ruminant animals

\begin{tabular}{|c|c|c|c|c|c|c|}
\hline \multirow[b]{2}{*}{ Animal } & \multirow[b]{2}{*}{ Number tested } & \multirow[b]{2}{*}{ Number positive } & \multirow[b]{2}{*}{ Positive (\%) } & \multicolumn{2}{|c|}{ Trypanosoma species identified (\%) } & \multirow[b]{2}{*}{ T. cong + T. brucei } \\
\hline & & & & T. cong & T. vivax & \\
\hline Cattle & 405 & 15 & $3.7^{\mathrm{a}}$ & $3(20.0)$ & $12(80.0)$ & $1(8.3)$ \\
\hline Goats & 486 & 6 & 1.2 & $5(83.3)$ & $1(16.7)$ & 0.0 \\
\hline Sheep & 470 & 5 & 1.1 & $3(60.0)$ & $2(40.0)$ & 0.0 \\
\hline Total & 1361 & 26 & 1.9 & $11(42.3)$ & $15(57.7)^{b}$ & $1(3.8)$ \\
\hline
\end{tabular}

T. cong. $=T$. congolense; As compared to goat and sheep ${ }^{a} \mathrm{p}<0.05\left(\chi^{2}=7.89, \mathrm{df}=2\right)$; As compared to T. congolense ${ }^{b} \mathrm{p}<0.05$

Table 2: Effect of gender of ruminants on prevalence rate of trypanosome infections

\begin{tabular}{|c|c|c|c|c|c|c|}
\hline \multirow[b]{2}{*}{ Animal } & \multirow[b]{2}{*}{ Gender } & \multirow[b]{2}{*}{ Number tested } & \multirow[b]{2}{*}{ Number positive $(\%)$} & \multicolumn{3}{|c|}{ Trypanosoma species identified } \\
\hline & & & & T. cong. & T. vivax & T. cong + T. bruce \\
\hline \multirow[t]{2}{*}{ Cattle } & Male & 206 & $9(4.3)$ & 2 & $7^{b}$ & 1 \\
\hline & Female & 199 & $6(3.0)$ & 1 & $5^{b}$ & 0 \\
\hline \multirow[t]{2}{*}{ Goats } & Male & 240 & $3(1.3)$ & $3^{c}$ & 0 & 0 \\
\hline & Female & 246 & $3(1.2)$ & 2 & 1 & 0 \\
\hline \multirow[t]{2}{*}{ Sheep } & Male & 251 & $2(0.8)$ & 1 & 1 & 0 \\
\hline & Female & 219 & $3(1.4)$ & 2 & 1 & 0 \\
\hline \multirow[t]{2}{*}{ Total } & Male & 697 & $14^{\mathrm{a}}(2.0)$ & 6 & 8 & 1 \\
\hline & Female & 664 & $12(1.8)$ & 5 & 7 & 0 \\
\hline
\end{tabular}

T. cong. $=T$. congolense $;{ }^{\#}=$ mixed infection; As compared to overall female ruminants ${ }^{\mathrm{a}} \mathrm{p}>0.05 ;$ As compared to $T$. congolense in cattle ${ }^{b} \mathrm{p}<0.001$; $\left(\chi^{2}=19.12, \mathrm{df}=1\right)$; As compared to $T$. vivax in goat ${ }^{\mathrm{c}} \mathrm{p}<0.05$ 
Table 3: Effect of host developmental status on ruminant trypanosomiasis

\begin{tabular}{|c|c|c|c|c|c|c|}
\hline \multirow[b]{2}{*}{ Type of animal } & \multirow[b]{2}{*}{ Age } & \multirow[b]{2}{*}{ No. tested } & \multirow[b]{2}{*}{ No. positive (\%) } & \multicolumn{3}{|c|}{ Trypanosoma species identified } \\
\hline & & & & T. cong. & T. vivax & T. cong + T. brucei \\
\hline \multirow[t]{2}{*}{ Cattle } & Young* & 105 & $5\left(4.8^{b}\right)$ & 1 & 4 & 0 \\
\hline & Adult & 300 & $10(3.3)$ & 2 & 8 & 1 \\
\hline \multirow[t]{2}{*}{ Goat } & Young* & 167 & $1(0.5)$ & 1 & 0 & 0 \\
\hline & Adult & 319 & $5(1.5)$ & 4 & 1 & 0 \\
\hline \multirow[t]{3}{*}{ Sheep } & Young* & 167 & $2(1.2)$ & 1 & 1 & 0 \\
\hline & Adult & 303 & $3(1.0)$ & 2 & 1 & 0 \\
\hline & Young* & 439 & $8\left(1.8^{a}\right)$ & 3 & 5 & 0 \\
\hline Total & Adult & 922 & $18(1.9)$ & 8 & 10 & 1 \\
\hline
\end{tabular}

${ }^{*}=\leq 1$ year (No permanent teeth); T. cong. $=$ T. congolense; As compared to overall adult ruminants ${ }^{\mathrm{a}} \mathrm{p}>0.05 ;$ As compared to adult cattle ${ }^{b} \mathrm{p}<0.05$

Table 4: Effect of season of the year on the prevalence of ruminant trypanosomiasis

\begin{tabular}{|c|c|c|c|c|c|c|}
\hline \multirow[b]{2}{*}{ Season } & \multirow[b]{2}{*}{ Type of animal } & \multirow[b]{2}{*}{ No. tested } & \multirow[b]{2}{*}{ No. positive (\%) } & \multicolumn{3}{|c|}{ Trypanosome species identified } \\
\hline & & & & T. cong. & T. vivax & T. cong $+T$. brucei \\
\hline \multirow[t]{4}{*}{ Dry } & Cattle & 295 & $4(1.3)$ & 1 & 3 & 1 \\
\hline & Goat & 314 & $1(0.3)$ & 1 & 0 & 0 \\
\hline & Sheep & 280 & $1(0.4)$ & 1 & 0 & 0 \\
\hline & Total & 889 & $5(0.5)$ & 3 & 3 & 1 \\
\hline \multirow[t]{4}{*}{ Rainy } & Cattle & 110 & $11(10.0)$ & 2 & 9 & 0 \\
\hline & Goat & 172 & $5(2.9)$ & 4 & 1 & 0 \\
\hline & Sheep & 190 & $4(2.1)$ & 2 & 2 & 0 \\
\hline & Total & 472 & $20\left(4.2^{*}\right)$ & $8^{*}$ & $12^{*}$ & 0 \\
\hline
\end{tabular}

Dry season = October to April; Rainy season = May to September; $T$. cong. $=T$. congolense; $* \mathrm{p}<0.001$ vs. dry season

Table 5: Effect of source of ruminant animals on the prevalence of trypanosome infection

\begin{tabular}{|c|c|c|c|c|c|c|}
\hline \multirow[b]{2}{*}{ Source of Sample } & \multirow[b]{2}{*}{ Animal } & \multirow[b]{2}{*}{ No. tested } & \multicolumn{4}{|c|}{ Trypanosoma species } \\
\hline & & & No. positive $(\%)$ & T. cong. & T. vivax & T. cong + T. bruxei \\
\hline \multirow[t]{4}{*}{ Resident animals } & Cattle & 25 & $1(4.0)$ & 0.0 & 1.0 & 0.0 \\
\hline & Goats & 262 & $1(0.4)$ & 1.0 & 0.0 & 0.0 \\
\hline & Sheep & 281 & $1(0.4)$ & 1.0 & 0.0 & 0.0 \\
\hline & Total $(\%)$ & 568 & $3(0.5)$ & $2(66.7)^{b}$ & $1(33.3)$ & 0.0 \\
\hline \multirow[t]{4}{*}{ Semi-nomadic } & Cattle & 185 & $8(4.3)$ & 2.0 & 6.0 & 0.0 \\
\hline & Goats & 0 & 0.00 & 0.0 & 0.0 & 0.0 \\
\hline & Sheep & 153 & $3(1.9)$ & 2.0 & 1.0 & 0.0 \\
\hline & Total $(\%)$ & 338 & $11(3.3)^{\mathrm{a}}$ & $4(36.4)^{c}$ & $7(63.6)$ & 0.0 \\
\hline \multirow[t]{4}{*}{ Slaughter houses } & Cattle & 195 & $6(3.1)$ & 1.0 & 5.0 & 1.0 \\
\hline & Goats & 224 & $5(2.2)$ & 4.0 & 1.0 & 0.0 \\
\hline & Sheep & 36 & $1(2.8)$ & 0.0 & 1.0 & 0.0 \\
\hline & Total $(\%)$ & 455 & $12(2.6)^{\mathrm{a}}$ & $5(41.7)^{d}$ & $7(58.3)$ & $1(8.3)$ \\
\hline
\end{tabular}

T. cong. $=T$. congolense As compared to resident animals ${ }^{\mathrm{a}} \mathrm{p}<0.001 ;$ As compared to $T$. vivax ${ }^{\mathrm{b}} \mathrm{p}<0.001 ;{ }^{\mathrm{c}} \mathrm{p}<0.01,{ }^{\mathrm{d} p}<0.05$

Effect of source of blood sample on ruminant trypanosomiasis: The results on source of sample are shown in Table 5. There was no significant difference ( $p>0.05$ ) in the prevalence of infection found among the semi-nomadic animals $(3.3 \%)$ and animals from slaughter houses $(2.6 \%)$ and in both cases, T. vivax (63.6 vs. 58.3\%) were higher.

Significantly lower $(\mathrm{p}<0.001)$ prevalence of trypanosome infection was recorded in resident animals when compared to semi-nomadic animals and animals from slaughter houses. In resident animals $T$. congolense was the predominant species encountered, the only mixed infection being that found in the slaughter house animals.

Effect of study location on ruminant trypanosome infections: The data on ruminant trypanosome infections obtained from different study locations are shown in
Table 6 . The prevalence in relation to study location was statistically significant $\left(\chi^{2}=18.47, \mathrm{df}=4, \mathrm{p}<0.001\right)$. In all the ruminant species, samples from Isuikwuato had significantly higher $(\mathrm{p}<0.001)$ prevalence of trypanosome infection than other study locations.

Ruminant trypanosomiasis in Nigeria has been recognised as serious constraint of livestock production and economic development with higher prevalence in cattle than in goats and sheep.

For all vector-borne parasitic diseases such as animal trypanosomiasis, transmission risk is directly related to the intensity of contacts between infected vectors and animal hosts. The risk of trypanosomiasis transmission and infection has not received attention in Abia State which serve as a major route for nomadic cattle rearing. Abia State is located mostly in the tropical rain 
J. Anim.Vet. Adv., 9 (18): 2422-2426, 2010

\begin{tabular}{|c|c|c|c|c|c|c|c|}
\hline \multirow[b]{2}{*}{ Type of animal } & \multirow[b]{2}{*}{ Number } & \multicolumn{6}{|c|}{ Study locations ${ }^{*}$} \\
\hline & & Ikwuano & Isiukwuato & Ohafia & Isiala-Ngwa & Umuahia-South & Total \\
\hline \multirow[t]{3}{*}{ Cattle } & Tested & 26.0 & 110.0 & 134.0 & 31.0 & 104.0 & 405.0 \\
\hline & Positive & 0.0 & 8.0 & 4.0 & 1.0 & 2.0 & 15.0 \\
\hline & positive (\%) & 0.0 & 7.3 & 3.0 & 3.2 & 1.9 & 3.7 \\
\hline \multirow[t]{3}{*}{ Goats } & Tested & 155.0 & 44.0 & 70.0 & 65.0 & 152.0 & 486.0 \\
\hline & Positive & 2.0 & 2.0 & 1.0 & 0.0 & 1.0 & 6.0 \\
\hline & positive (\%) & 1.3 & 4.5 & 1.4 & 0.0 & 0.7 & 1.2 \\
\hline \multirow[t]{3}{*}{ Sheep } & Tested & 166.0 & 25.0 & 37.0 & 41.0 & 201.0 & 470.0 \\
\hline & Positive & 0.0 & 2.0 & 2.0 & 0.0 & 1.0 & 5.0 \\
\hline & positive (\%) & 0.0 & 8.0 & 5.4 & 0.0 & 0.4 & 1.1 \\
\hline \multirow[t]{3}{*}{ Total } & Tested & 347.0 & 179.0 & 241.0 & 137.0 & 457.0 & 1361.0 \\
\hline & Positive & 2.0 & 12.0 & 7.0 & 1.0 & 4.0 & 26.0 \\
\hline & positive (\%) & 0.6 & $6.7^{\mathrm{a}}$ & 2.9 & 0.7 & 0.9 & 1.9 \\
\hline
\end{tabular}

${ }^{*} \chi^{2}=18.47$ (Significant, $d f=4, p<0.001$ ); As compared to other locations ${ }^{a} \mathrm{p}<0.001$

forest or derived savannah vegetational zone and in the humid agro-ecozone, however there is dearth of information on the epidemiology of ruminant trypanosomiasis in the area for comparative discussion. The prevalence of ruminant trypanosomiasis reported in this study was less than those reported in northern (Agu et al., 1989; Nawathe et al., 1995; Dadah et al., 1997) and central Nigeria (Omotainse et al., 2000). This could be attributed to lower vector abundance with low infection rates recorded here (Ohaeri, 2005; Ohaeri and Eluwa, 2007) which may be associated with lower prevalence of trypanosome infection in the animal hosts. Ruminant trypanosomiasis and its vector, Glossina species have been found to be endemic in some parts of Nigeria and their presence in Abia State, though of low prevalence is a conclusive evidence of the endemicity.

The higher number of T. vivax found at this point agrees with most findings in many parts of Nigeria (Agu et al., 1989; Kalu et al., 1991, 1996; Ikede, 1991; Omotainse et al., 2000) that T. vivax infection is more prevalent. Male cattle had more infection and this differs from the findings of Kalu et al. (1996) in Jos, Plateau but is in agreement with Kalu (1995) research on trypanotolerant cattle in Lower Benue area. Also the only mixed infection (T. congolense $+T$. brucei) was found in male cattle. The explanation here might be that there is more influx of male cattle from the north into the study area, sold for food as against the female and some of which might be infected prior to entry into the area.

The present result on age related prevalence differs from the work of Kalu et al. (1996) who found more infection in adult ruminants in Kastina-ala Local Government Area, central Nigeria but are similar to those documented by Ryan et al. (1982). There was also no age effect on the two predominant species encountered. The only case of simultaneous infection ( $T$. congolense + T. brucei) was found in adult cattle. Since T. brucei was absent in all the flies dissected (Ohaeri, 2005) this made the source of the infection uncertain: possibly the cattle was pre-infected before entering the study area. The lower prevalence of trypanosome infection of ruminant observed during the dry season was associated with lower vector abundance and infection rates (Ohaeri, 2005). Agu et al. (1989) reported higher prevalence of ruminant infection with higher density of infected vectors in Kaduna and Plateau State.

\section{CONCLUSION}

In this study, the differences in infection rates among the animals studied in different locations can be explained on the basis of reduced vector-host contact especially in some areas like Ikwuano where a small number of cattle were encountered or due to high concentration of nomadic cattle rearing in Isuikwuato.

The high prevalence of trypanosome infection in semi-nomadic and slaughter animals might further mean that some animals were infected prior to entry into the study area or infected stock were sold for slaughter. In other words lower prevalence of trypanosome infection encountered among resident animals may imply poor vectoral capacity of the tsetse in the study area or low density of flies in association with low infection rate (Ohaeri, 2005) or unavailability of infected host for the flies to feed on. Besides, significant number of the resident animals might be trypanotolerant. These findings therefore evidently entail that Abia State stands a good ground for sustainable livestock production.

\section{ACKNOWLEDGEMENTS}

This study was supported by Education Trust Fund (ETF) and formed part of a Ph.D thesis submitted to Michael Okpara University of Agriculture, Umudike, Abia State Nigeria. We are grateful to Professor M. C. Eluwa for excellent supervision, Professor M. Uzoukwu for advice and also to Mr C.F. Onwuchuruba and Mr S.N. Okereke for rendering help in sample collection. 


\section{REFERENCES}

Agu, W.E., J.O. Kalejaiye and O.A. Olatunde, 1989. Prevalence of bovine trypanosomosis in kaduna and plateau state of Nigeria. Bull. Anim. Health Prod. Afr., 37: 161-166.

Dadah, A.J., D.D. Duliska-Popova, A.D. Daniel and P.M. Dede, 1997. Trypanosomiasis among sheep and goats at slaughter in jos abattoir, Nigeria. Rev. Elev. Vet. Pays. Trop., 50: 214-216.

Ikede, B.O., 1991. Control of animal trypanosomiasis in Nigeria as a strategy for increased livestock production. Proceedings Preparatory workshop, June 5-9, Vom, Plateau State (Nigeria). 150-150.

Kalu, A.O., M. Uzoukwu and M. Ikeme, 1996. Prevalence of tsetse fly and ruminant trypanosomiasis in katsinaala local gernmebt area, Nigeria. Rom. Arch. Microbiol. Immunol. T., 55: 341-352.

Kalu, A.U. and F.A. Lawani, 1996. Observations on the epidemiology of ruminant trypanosomosis in Kano State, Nigeria. Rev. Elev. Med. Vet. Pays Trop., 49: 213-217.

Kalu, A.U., 1995. Prevalence of trypanosomiasis among trypanotolerance cattle at the lower Benue River area of Nigeria. Prev. Vet. Med., 24: 97-103.

Kalu, A.U., M. Uzoukwu, M.M. Ikeme and Y. Magaji, 1991. Trypanosomiasis in Nigeria: High prevalence among ruminants in gboko local government area. Bull. Anim. Hlth. Prod. AFR., 39: 3-8.

Kalu, A.U., S.I. Oboegbulem and M. Uzoukwu, 2001. Trypanosomiasis in small ruminants maintained by low riverine tsetse population in central Nigeria. Small Ruminant Res., 40: 109-115.

Luckins, A.G., 1992. Trypanosomiasis in small ruminants: A major constraint to livestock production. Brit. Vet. J., 148: 471-473.
Masiga, D.K., G. Okech, P. Irungu, J.O. Ouma and S. Wekesa et al., 2002. Growth and mortality in sheep and goats under high tsetse challenge in Kenya. Trop. Anim. Health Prod., 34: 289-501.

Murray, M., P.K. Murray and W.I.M. Mclntyre, 1977. An improved parasitological technique for the diagnosis of African trypanosomiasis. Trans. Roy. Soc. Trop. Med. Hyg., 71: 325-326.

Nawathe, D.R., G.C. Srivastava, A.K. Basu and M.A. Kollere, 1995. Trypanosomiasis in small ruminants in the arid zone, Nigeria. Bull. Anim. Hlth. Prod. Afr., 43: 293-294.

Ohaeri, C.C. and M.C. Eluwa, 2007. The population structure and physiological status of tsetse flies in Abia State, Nigeria. J. Anim. Vet. Adv., 6: 513-516.

Ohaeri, C.C., 2005. Tsetse and Ruminant trypanosomiasis in Abia State Nigeria. Ph.D. Thesis, Michael Okpara University of Agriculture Umudike Abia State, Nigeria.

Omotainse, H., G.A. Edeghere, E.O. Omoogum, C.A. Elhassan and J.A.C. Igweh, 2000. The prevalence of animal trypanosomiasis in konshisha local government area of Benue State, Nigeria. Israel Vet. Med. Assoc., 55: 1-3.

Paris, J., M. Murray and F.A. McOdimba, 1982. Comparative evaluation of the parasitological methods currently available for the diagnosis of African trypanosomiasis in cattle. Acta Trop., 37: 307-316

Ryan, L., W. Kupper, S.L. Goff, D.H. Molyneux and M. Clair, 1982. Differences in rates of acquisition of trypanosome infection between Glossina species in the field. Ann. Soc. Belg. Med. Trop., 62: 291-300.

Ugochukwu, I., 1983. Caprine trypanosomiasis caused by trypanosoma congolense. Acase Report. Nig. Vet. J., 12: $24-27$. 